\title{
A study on the changes of the consumption level of rural residents Xuechao Ma ${ }^{1, a}$, Hong Yin ${ }^{1, b}$ and Meng Lv ${ }^{1, c}$ \\ ${ }^{1}$ Mechanical and Electrical Engineering College, Kunming University of Science and Technology,kunming,China a4415500515@qq.com, b2473664405@qq.com, ${ }^{c} 545340192 @ q q . c o m$
}

Keywords:Household consumption level; consumption structure; stepwise regression Abstract. Under the condition of market economy, the demand is the leading force of the market, and the constraint function and the function of the economy will become more and more obvious. China is now in a market economy to accelerate the transition period, the impact of consumption on its economic development is particularly significant. This paper mainly through the search 2005-2014 China Statistical Yearbook related data descriptive statistics, factor analysis, stepwise regression statistical methods to the level of development of consumption, consumption structure and influencing factors of rural residents' research .Get the change of the residents' consumption structure and the law, the main restrict factors of the residents' consumption level, so as to predict the trend of the consumer market.

\section{Introduction}

With the continuous development of China's economy, expanding domestic demand, especially consumer demand has become the basic foothold and long-term strategic policy to promote the steady development of the national economy. At this stage, it is necessary to rely on the expansion of domestic demand, especially the consumption demand of rural residents to promote economic development [1].

From a theoretical point of view, the specific content of consumer demand mainly embodied in the structure of consumption to increase the consumption of residents. Only by understanding the trend and the law of changes in the consumption structure of rural residents and grasp the focus and direction of development of consumer demand, to guide the rational consumer to expand consumption, in order to promote the adjustment of industrial structure and consumption structure optimization and upgrading of coordination, in order to promote the stable and healthy development of national economy.

\section{Research Contents and Methods}

In this paper, the average consumption level of rural residents in China are studied. Through the analysis of the eight aspects of consumption. Finally get the main consumption of the consumer market, so as to play a guiding role in the market. According to 10 years China's rural residents consumption data and influence factors data using descriptive statistics and stepwise regression, cluster analysis, the establishment of mathematical model and other statistical methods to solve the economics, consumption market trend towards practical problems. 


\section{Establish a preliminary regression model}

From 2005 to 2014, the average household consumption expenditure of rural households in China (yuan). We mainly study the average consumption level of the residents in the whole country through the relevant data of table 1. In this selection of the impact of the average price index of 8 factors. Therefore, the impact of different consumer value consumer level lies mainly in its sales prices and sales volume. The main use of multiple regression analysis, to explore the impact on the average price of the dominant factor, and the regression model. Initial model is as follows:

$\mathrm{Y}=\mathrm{b} 0+\mathrm{b} 1 * \mathrm{x} 1+\mathrm{b} 2 * \mathrm{x} 2+\mathrm{b} 3 * \mathrm{x} 3+4 \mathrm{~b} * \mathrm{x} 4+\mathrm{b} 5 * \mathrm{x} 5+\mathrm{b} 6 * \mathrm{x} 6+\mathrm{b} 7 * \mathrm{x} 7+\mathrm{b} 8 * \mathrm{x} 8+\mathrm{u}$

Form 1 national consumption expenditure in rural areas[2]

\begin{tabular}{|c|c|c|c|c|c|c|c|c|c|}
\hline Annual data & & & & & & & & & \\
\hline Whole country & & & & & & & & & \\
\hline Time & $\mathrm{Y}$ & $\mathrm{x} 1$ & $\mathrm{x} 2$ & $\mathrm{x} 3$ & $\mathrm{x} 4$ & $\mathrm{x} 5$ & $\mathrm{x} 6$ & $\mathrm{x} 7$ & $\mathrm{x} 8$ \\
\hline 2014year & 6625.5 & 2496 & 438.3 & 1234 & 387.1 & 796 & 486 & 614.2 & 174.9 \\
\hline 2013year & 5908 & 2324 & 396.4 & 1086 & 341.7 & 653 & 446 & 513.8 & 147.6 \\
\hline 2012year & 5221.1 & 2107 & 341.3 & 961.5 & 308.9 & 547 & 396 & 436.8 & 122 \\
\hline 2011year & 4381.8 & 1801 & 264 & 835.2 & 234.1 & 461 & 367 & 326 & 94 \\
\hline 2010year & 3993.5 & 1636 & 232.5 & 805 & 204.8 & 403 & 341 & 287.5 & 84.1 \\
\hline 2009year & 3660.7 & 1599 & 211.8 & 678.8 & 174 & 360 & 315 & 246 & 76.7 \\
\hline 2008year & 3223.9 & 1389 & 193.5 & 573.8 & 149.1 & 328 & 306 & 210.2 & 74.2 \\
\hline 2007year & 2829 & 1217 & 168 & 469 & 126.6 & 289 & 305 & 191.5 & 63.1 \\
\hline 2006year & 2555.4 & 1162 & 148.6 & 370.2 & 111.4 & 245 & 296 & 168.1 & 54.5 \\
\hline 2005year & 2184.7 & 1032 & 120.2 & 324.3 & 89.2 & 193 & 248 & 130.6 & 48.3 \\
\hline
\end{tabular}

$\mathrm{x} 1$ :Food consumer price index

$\mathrm{x} 2$ :Tobacco and liquor consumer price index

$\mathrm{x} 3$ :Clothing consumer price index

$\mathrm{x} 4$ :Household equipment and maintenance services consumer price index

$\mathrm{x} 5$ : Consumer price index for health care and personal products

$\mathrm{x} 6$ :Consumer price index for transportation and communication

$\mathrm{x} 7$ :Consumer price index for entertainment and educational products and services

$\mathrm{x} 8$ :Residential consumer price index

b1,b2,b3,b4,b5,b6,b7,b8-Unknown parameter

$\mathrm{U}$ is Residual error and $\mathrm{E}(\mathrm{u})=0$ and Has nothing to do with the 8 independent variables. 


\section{Establish regression equation}

Form 1 data were analyzed by linear correlation test. As follows :

Picture 1 A linear scatter plot between the variables

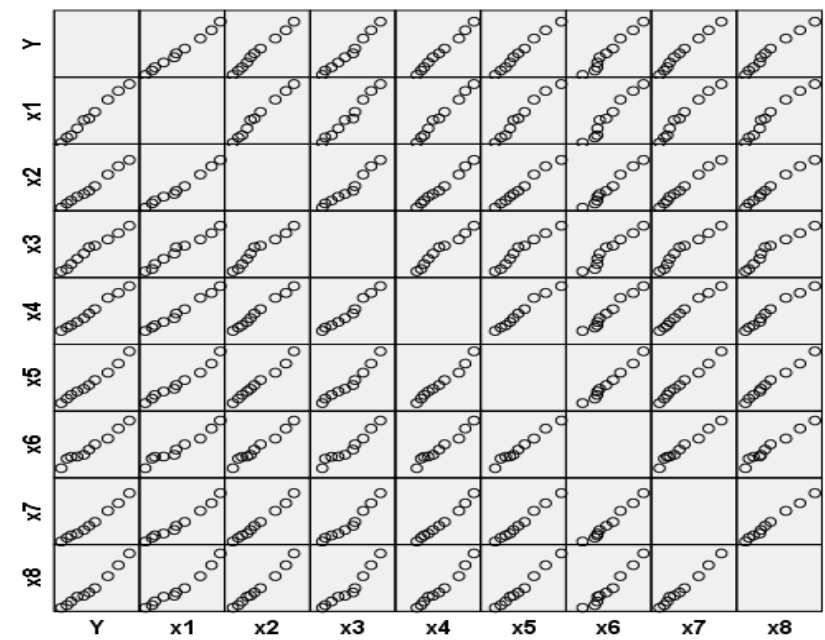

Analysis:Form Picture 1 shows that a linear relationship existed between all independent variables and the dependent variable. So in each of the dependent variable will effect on the variable changes. The various indicators combined factors do have significant influence on the average consumption level of residents.

The analysis of data processing with SPASS and get the regression data table as follows:

Form 2 Coefficient table

\begin{tabular}{|c|c|c|c|c|c|c|}
\hline & \multirow[t]{2}{*}{ Model } & \multicolumn{2}{|c|}{$\begin{array}{l}\text { Unstandardized } \\
\text { Coefficients }\end{array}$} & \multirow{2}{*}{$\begin{array}{c}\text { Standardized } \\
\text { Coefficients } \\
\text { The trial version }\end{array}$} & \multirow[t]{2}{*}{$\mathrm{t}$} & \multirow[t]{2}{*}{ Sig. } \\
\hline & & B & Standard error & & & \\
\hline \multirow{9}{*}{1} & (constant) & 6.792 & 20.403 & & .333 & .795 \\
\hline & $\mathrm{x} 1$ & .992 & .012 & .338 & 81.670 & .008 \\
\hline & $\mathrm{x} 2$ & 1.082 & .171 & .079 & 6.316 & .100 \\
\hline & $\mathrm{x} 3$ & .998 & .009 & .207 & 105.517 & .006 \\
\hline & $\mathrm{x} 4$ & 1.025 & .107 & .071 & 9.575 & .066 \\
\hline & $\mathrm{x} 5$ & 1.020 & .059 & .131 & 17.171 & .037 \\
\hline & x6 & .978 & .084 & .049 & 11.679 & .054 \\
\hline & $\mathrm{x} 7$ & .972 & .063 & .106 & 15.509 & .041 \\
\hline & $\mathrm{x} 8$ & .895 & .369 & .025 & 2.425 & .249 \\
\hline
\end{tabular}

Form 3 Residual statistics table

\begin{tabular}{|l|c|c|c|c|c|}
\hline & Minimum & maximum & Means & standard deviation & $\mathrm{N}$ \\
\hline prediction & 2185.0039 & 6625.4014 & 4058.3600 & 1476.00939 & 10 \\
Residuals & -.36937 & .26868 & .00000 & .23354 & 10 \\
standard & -1.269 & 1.739 & .000 & 1.000 & 10 \\
prediction & & & & .333 & 10 \\
standard & -.527 & .383 & .000 & & \\
Residuals & & & & & \\
\hline
\end{tabular}


The data in Table 5 coefficients associated table B column into the regression equation regression model.

$\mathrm{Y}=6.792+0.992 \times 1+1.082 \times 2+0.998 \times 3+1.025 \times 4+1.020 \times 5+0.978 \times 6+0.972 \times 7+0.895 \times 8$

From the above, the level of consumption of rural residents is the dominant role of the average per capita food consumption expenditure of rural households and others were relatively low. But the gap between urban and rural areas is a country developed standard. From the current situation of consumption of rural residents is still relatively backward stage. Therefore The country must adjust industrial structure appropriately and vigorously develop the rural economy to catch up with the pace of the city. The people are rich, powerful countries will[3].

\section{Table 1 Analysis by SPASS}

Form 4 The common factor variance table

\begin{tabular}{|l|c|c|}
\hline & initial & extract \\
\hline $\mathrm{Y}$ & 1.000 & .998 \\
$\mathrm{x} 1$ & 1.000 & .990 \\
$\mathrm{x} 2$ & 1.000 & .997 \\
$\mathrm{x} 3$ & 1.000 & .972 \\
$\mathrm{x} 4$ & 1.000 & .995 \\
$\mathrm{x} 5$ & 1.000 & .994 \\
$\mathrm{x} 6$ & 1.000 & .983 \\
x7 & 1.000 & .994 \\
$\mathrm{x} 8$ & 1.000 & .986 \\
\hline
\end{tabular}

Extract method:principal component analysis.

The form is a common factor variance report which the amount of variance explained that each variable. Initial Communalities are each variable is variance for all ingredients or interpretation of the estimate factor. For the principal component analysis is that always equal to 1.Because of the number of original variables have many ingredients (Communalitie), so the common will be equal to 1 .

Extraction of common factor variance is a factor in the solution of each variable is the variance factor or component interpretation estimator. The common factor variance is used to predict the factor variables of multiple correlation squared. The numerical value is smaller, it shows that the variable is not suitable for factor that can be excluded in the analysis. This table shows the numerical factor variance extracted are relatively large, so cannot remove.

From the table to extract only a principal component factor $\mathrm{F}$ and different consumer price average price of Factor Analysis Model:

$$
\mathrm{Y}=0.999 ; \mathrm{X} 1=0.995 \mathrm{~F} ; \mathrm{X} 2=0.998 \mathrm{~F} ; \mathrm{X} 3=0.986 \mathrm{~F} ; \mathrm{X} 4=0.997 \mathrm{~F} ; \mathrm{X} 5=0.997 \mathrm{~F} ; \mathrm{X} 6=0.991 \mathrm{~F} ; \mathrm{X} 7=0.997 \mathrm{~F} \text {; }
$$
$\mathrm{X} 8=0.993 \mathrm{~F}$

From the Factor Analysis Model can see that eight indicators on the main factor F loads above 0.9, it represents the level of consumer. As apparent from Table that Main factor X1 contribution rate has reached $99.9 \%$. Therefore, it is stated that food consumption is the most important aspect. 
Form 5 Component matrix

\begin{tabular}{|c|c|}
\hline & Component \\
\cline { 2 - 3 } & 1 \\
\hline Y 1 & .999 \\
x2 & .995 \\
x3 & .998 \\
x4 & .986 \\
x5 & .997 \\
x6 & .997 \\
x7 & .991 \\
x8 & .997 \\
\hline
\end{tabular}

Extract method: main ingredient.

a. It has been extracted an ingredient.

\section{Conclusion}

On the level of consumption of residents is the role of food consumption. So we can see that the consumption of the rural economy is spent on food. Although people breeds, but a country's prosperity must is the prosperity of the people of the whole nation, not only is the prosperity of the city. So let the rural people accept the scientific and advanced education is the most important way to improve people's comprehensive quality, working ability and creative practice ability.. This is first of all to guarantee their effective income.

In the next few years people spend in the food category is showing a rising trend. So I think that the state should vigorously support the rural economy. Such as adjusting the industrial structure of agriculture and livestock production support and Strengthen the mechanization of rural equipment In terms of infrastructure, we should strengthen the construction of roads, water conservancy facilities and so on. the construction of professional cooperative economic organizations and agricultural products brand building.By factor analysis, the average consumption level of rural residents is the main aspect of the living standard in different time. Food dominated in the structure of expenditures. The continuous improvement of rural expenditure balance, to improve people's living standards and the rapid development of the national economy pull.

\section{References}

[1] Xiaoqun He. multivariate statistical analysis. China Renmin University Press(2012)

[2] National Bureau of Statistics. China Statistical Yearbook. China Statistics Press(2013)

[3] Jun Wu. SPSS statistical analysis to learn from scratch. Tsinghua University Press(2014) 